\title{
The Integrated Physics Learning E-Module with Pancasila Character Values in Work and Energy Subjects as Solution to Improve Students' Critical Thinking Ability and Independence: Is It Effective?
}

\author{
Aprilia Mayang Sari ${ }^{1 *}$, Ariswan $^{2}$ \\ ${ }^{1,2}$ Graduate School of Physics Education, Universitas Negeri Yogyakarta, Yogyakarta, Indonesia. \\ *Corresponding Address: apriliamayangsari46@gmail.com
}

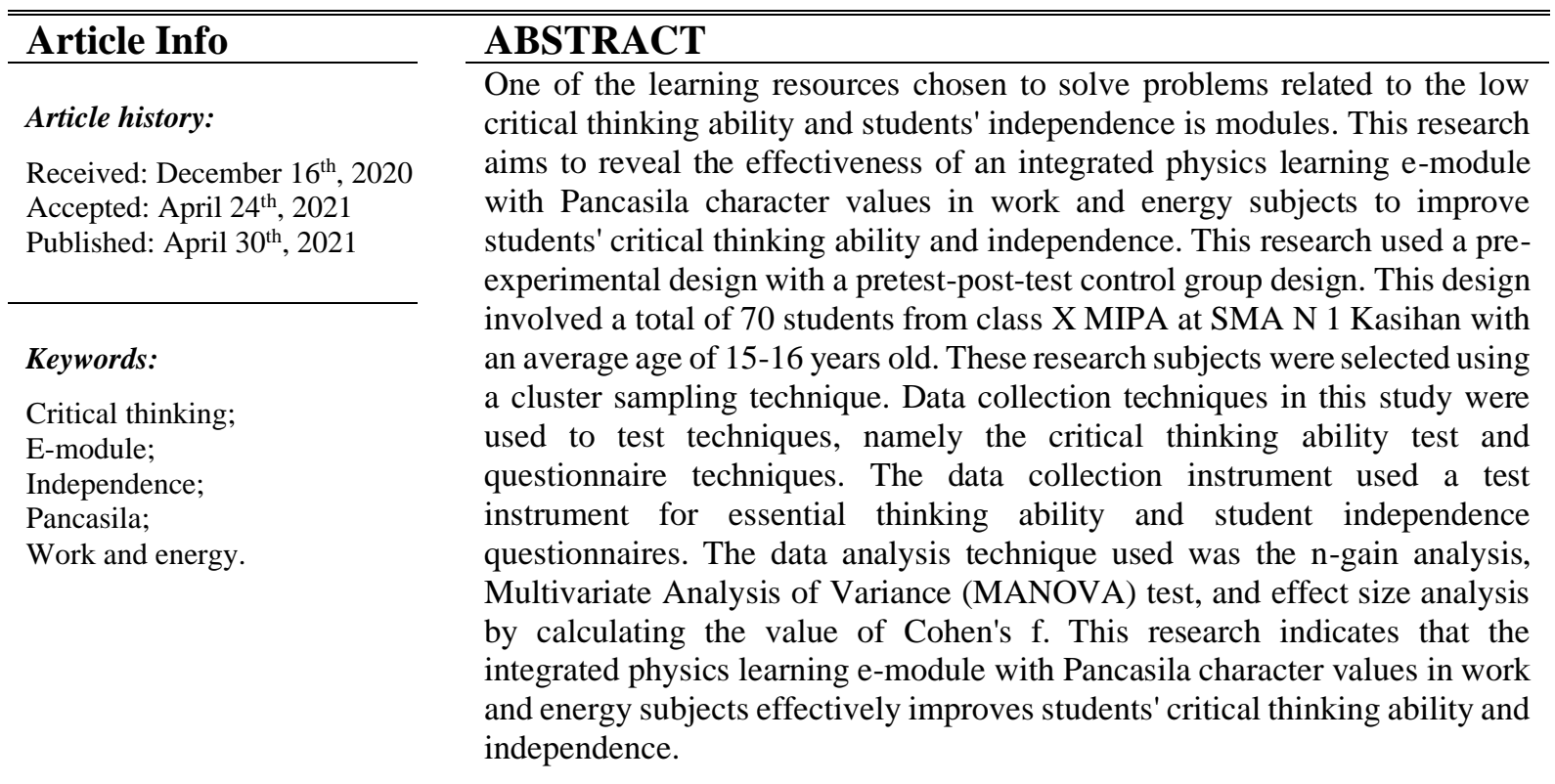

(C) 2021 Physics Education Department, UIN Raden Intan Lampung, Indonesia.

\section{INTRODUCTION}

The implementation of education obtained a considerable influence from the development of the global era and other aspects of life (Ghozali \& Wahyuningsih, 2017; Sunaengsih, 2017). The global period presents explicit challenges for the world of education. Education should produce quality human resources with noble character and have comprehensive abilities to live life in the 21st-century era (Ahmadi \& Ibda, 2018; Izzati et al., 2019). In this regard, various aspects of Indonesia's national education must be changed or rearranged so that education is increasingly capable of making a real and meaningful contribution to Indonesia's gait and progress in the $21 \mathrm{st}$ century (Buana \& Kasanah, 2019; Kurniasih et al., 2018; Musawwamah, 2019).

The restructuring or changes to Indonesia's national education can be initiated by putting back the characters derived from Pancasila, which is the way of life of the Indonesian people, as the soul or the innermost dimension of national education along with the intellectuality painted incompetence (Janah et al., 2018). Through strong character coupled with high competence generated through excellent teaching, all new necessities, demands, and challenges meet or handle (Anita \& Novianty, 2020).

One of the competencies and characters that must be owned and developed to equip 
students in the 21 st century is critical thinking ability and independence (Wrahatnolo \& Munoto, 2018). Critical thinking ability is the ability of a person to employ evidence and data to decide what to do and believe (Walsh et al., 2019). This ability could encourage students in the process of collecting, interpreting, analyzing, and assessing to appeal accurate and reliable conclusions (Saputra \& Kuswanto, 2019). In physics learning, this ability can help physicists or students to be able to understand data, assess whether the data obtained is trusted, compare it to samples, also decide what to do when thinking about the experiment of physics, interpret scientific reports in various sources, or make the decision of public policy (Walsh et al., 2019). While the character of independence is an attitude to behave and act that is not dependent or tied to other people (Supardi, 2018). This character prepares students to use all their energy, time, and thoughts to realize dreams, hopes, and aspirations to produce a resilient, hard, courageous person, and so on (Tanti et al., 2020). In learning physics, this character helps students do experiments independently, carry out active searches or build their knowledge (Siswanto et al., 2016).

In connection with this, several research results show the students' critical thinking ability is yet included in the weak category, especially in physics, in work and energy subjects (Harjo et al., 2019; Nurazizah et al., 2017). In addition to these problems, the world of education in Indonesia is currently facing other issues, namely the tendency of moral degradation, character, and ethics, including issues related to student independence (Derlina \& Srijayanti, 2016; Malihah, 2015). Various facts in the field show that the student's freedom is still weak (Labudasari \& Rochmah, 2019; Saefullah et al., 2017).

Various problems related to critical thinking ability and independence can be overcome by choosing the right learning source (Asrial et al., 2020). Learning resources that will be used in learning must facilitate students to improve their critical thinking ability and independence (Aulia et al., 2019; Nisa et al., 2018). One of the learning resources that can be chosen is modules (Aprilia \& Suryadarma, 2020). The module was chosen because it has many advantages which can support independent learning (Husna et al., 2021; Rufii, 2015). The material presented in the module can also be designed to train students to increase their critical thinking ability (Ummah et al., 2020). In addition, in line with the pressure that demands a balance between character education and intellectuality, the presentation of material in the module can also be integrated with the Pancasila character values (Ariyani et al., 2018; Ramadoni et al., 2019).

Pancasila is the state philosophy and way of life for the Indonesian people. As the basis of the state and as a way of life, Pancasila contains noble values that must be lived and guided by all Indonesian citizens (Adi, 2016). These character values can be explored and taught through physics. For example, in physics, the work done by several forces at the same point is the algebraic sum of the work done by each force. Through this concept, we can teach about responsibility. By analogy, great goals cannot be achieved if it is not pursued together to fit for us in our lives to carry out our respective responsibilities to join in trying to achieve our goals together. When combined, the efforts of each member will result in a more significant effort to achieve the goals.

Along with the very rapid advancement of technology, the presentation and use of modules in learning today can be done with electronic format (e-module) (Astra et al., 2020). The electronic module or e-module has its advantages compared to print modules in general (Agung et al., 2020). These advantages include modules that can be inserted with audio, animation, movies, to navigation (Sadaghiani, 2012). Besides that, the electronic module can be used anywhere and anytime (Darmaji et al., 2019). These various advantages can make the 
information display more structured attractively, have high interactivity, practically, and make the module durable and not damaged by time (Kurniawan \& Syafriani, 2020).

The reality in the field shows that the modules available and used in learning today are still not capable of practicing students to think critically (Syawaludin et al., 2019). The modules used are also not fully able to develop the character of the students (Susanti \& Djukri, 2018). In addition, the modules used for learning are not fully integrated with the Pancasila character's values (Chrisyarani \& Yasa, 2018; Putri et al., 2017). Some research results show that electronic modules or e-modules are still underutilized in learning (Sofyan et al., 2019).

Related to this, several studies have been conducted. Retnowati (2020) developed a rectangular module by a STEM approach to increasing critical thinking ability. The results show that the module effectively increases essential thinking ability (Retnowati et al., 2020). Astuti (2019) developed a responsibility character module. The results show that the module can be applied in the independent learning context (Astuti \& Mufrihah, 2019). Sopacua (2020) is also developed a history learning module that integrated character values. The result is that the module is practical, feasible, and effective to apply as student learning resources and teaching materials (Sopacua et al., 2020).

In the end, it can be known that critical thinking ability and independence are necessary for students in life, one of which can be developed or improved through education. One way to do this is by providing learning resources that can facilitate students to think critically and train their independence. But on the other hand, the availability of these resources is still relatively minimal and less used in the field. Several previous studies have shown several possibilities for developing a learning resource such as a module that can train students to think critically or integrated with specific noble values to build student character. Accordingly, based on these various things, an integrated physics learning e-module with Pancasila character values in work and energy subjects was developed and used as a solution to improve student's critical thinking ability and independence. This module is designed to contain physics subjects, namely work and energy, designed to help students improve their thinking ability and integrate with the Pancasila character values, including matters related to the independent character. So, this module can also help students improve their character. Besides that, this module is also designed in an electronic format. Its use is focused on revealing the effectiveness of an e-module in enhancing students' critical thinking ability and independence.

\section{METHODS}

This research used a pre-experimental design with a pretest-post-test control group design. The design involved two classes as an experiment class and a control class. The experiment class used an integrated physics learning e-module with Pancasila character values in work and energy subjects. This emodule contains sub material, namely, work, energy, work, energy relations, and the law of conservation of mechanical energy. EModule has several components including 1) front page, 2) e-module menu,3) introduction which contains an introduction, learning instructions, competencies, and concept maps, 4) three learning activities, each of which contains an apperception video, "lets an exploration of your knowledge," "let's investigate," and "let's evaluate," 5) summaries, 6) formative test, 7) answer keys, 8) reference, and 9) developer profile. Through this e-module, students are exposed to sample questions, practice questions, and test questions adjusted to the indicators of critical thinking ability, namely analyzing facts/ problems, formulating problems main, defending/ selecting/ clarifying/ evaluating logical arguments, and making decisions/ conclusion. In addition, students are also 
exposed to the material presentation, sample questions, and other test questions that are integrated with the Pancasila character values. Many character values are incorporated into this e-module, and some of them are character values related to the independent character, such as hard work, responsibility, independence, and so on. These values are extracted from work and energy subjects and integrated into emodules through life analogies and exemplary examples of the Pancasila practice.

On the other hand, the control class used textbooks that students commonly used. Each class is given a test before treatment (pretest) and given a test again after treatment (post-test). The design of this research is presented in Table 1 (Noor, 2017).

Table 1. Research Design

\begin{tabular}{cccc}
\hline Class & Pretest & Treatment & $\begin{array}{c}\text { post- } \\
\text { test }\end{array}$ \\
\hline Experiment & $\mathrm{O}_{1}$ & $\mathrm{X}_{1}$ & $\mathrm{O}_{2}$ \\
Control & $\mathrm{O}_{1}$ & $\mathrm{X}_{2}$ & $\mathrm{O}_{2}$ \\
\hline
\end{tabular}

Information:

$\mathrm{O}_{1}$ : Pretest $\mathrm{O}_{2}$ : post-test

$\mathrm{X}_{1}$ : Using the integrated physics learning emodule with Pancasila character values.

$\mathrm{X}_{2}$ : Using textbooks that students usually use.

Research subjects in this study were taken from two classes of SMA N 1 Kasihan. Class $\mathrm{X}$ MIPA 3 was the experimental class that consisted of 36 students and X MIPA 5 as the control class, which consisted of 34 students. These students have an average age of 15-16 years old and have studied physics material before but not yet for work and energy. The subjects, totaling 70 students, were selected using a cluster sampling technique. The flowchart of this research can be seen in Figure 1.
Development of Integrated Physics Learning E-Module with Pancasila Character Values in Work and Energy Subjects

Determination of experiment method with pretest-post-test control group design.

This method involved a total of 70 students for the experiment and control classes as research subjects.

Implementation of the of Integrated Physics Learning E-Module with Pancasila Character Values in Work and Energy Subjects

- Students were given a critical thinking ability test and an independent questionnaire before treatment.

- Students were given treatment.

- Students were given a critical thinking ability test and an independent questionnaire after treatment.

Analysis of Students' Critical Thinking Ability and Independence

$\mathrm{N}$-gain analysis, Multivariate Analysis of Variance (MANOVA) test, and effect size analysis.

Figure 1. The Research Flowchart

Data collection techniques in this research were used to test techniques and questionnaire techniques. The research instruments were used, namely the critical thinking ability test instrument and the student independence questionnaire. The critical thinking ability test instrument contains ten questions in the form of essays on work and energy subjects. These questions are adjusted to the indicators of critical thinking ability. The indicators are the same as the indicators of critical thinking ability questions in the e-module. At the same time, the student independence questionnaire contains 37 statement items that are arranged based on the indicators of independence, including not depending on others, self-confidence, responsibility, initiative, and perseverance.

The data that has been collected is then analyzed to reveal the effectiveness of the e- 
module in improving students' critical thinking ability and independence. This effectiveness analysis is based on three analyzes, namely the analysis of improving students' critical thinking ability and independence in each class, analysis of differences in students' critical thinking ability and independence between the experiment class and the control class, and the effect analysis of using e-modules on improving students' critical thinking ability and independence.

Analysis of the improvement of students' critical thinking ability and independence in each class was carried out with normalized gain $(\mathrm{g})$. The analysis using normalized gain is shown in equation (1)(Hake, 1998).

$$
\langle g\rangle=\frac{\text { posttest score }- \text { pretest score }}{\text { maximum score-pretest score }}
$$

The gain index criteria, according to Hake, are shown in Table 2 (Hake, 1998).

Table 2. Gain Index Criteria

\begin{tabular}{cc}
\hline Gain Index & Criteria \\
\hline$g>0.70$ & High \\
$0.30<g<0.70$ & Moderate \\
$g \leq 0.30$ & Low \\
\hline
\end{tabular}

The analysis of differences in students' critical thinking ability and independence between the experiment and control classes was carried out using the Multivariate Analysis of Variance (MANOVA) statistical test. This test was carried out with the help of SPSS 16.0 software, but before that, a prerequisite test was carried out, namely the normality test and the homogeneity test. Meanwhile, the effect analysis of using emodules on improving students' critical thinking ability and independence was carried out by reading the Test of BetweenSubject Effects output on the MANOVA test. The magnitude of the influence/ effectiveness of the e-module on improving students' critical thinking ability and independence is seen using the effect size calculated by Cohen's equation as in equation (2)(Cohen, 1988).

$$
f=\sqrt{\frac{\eta^{2}}{1-\eta^{2}}}
$$

Cohen's $\mathrm{f}$ category is presented in Table 3 (Cohen, 1988).

Table 3. Interpretation of Effect Size Value

\begin{tabular}{cc}
\hline Value of Cohen's $\mathbf{f}$ & Interpretation \\
\hline $0.0 \leq f<0.10$ & Weak \\
$0.10 \leq f<0.25$ & Moderate \\
$0.25 \leq f<0.4$ & Strong \\
$0.4 \leq f$ & Very Strong \\
\hline
\end{tabular}

\section{RESULTS AND DISCUSSION Results}

In this research, the experiment class used the integrated physics learning e-module with Pancasila Character Values. Some examples of this e-module display are presented in Figure 2 to Figure 4.

\section{E-Modul \\ Pembelajaran Fisika}

USAHA DAN ENERGI

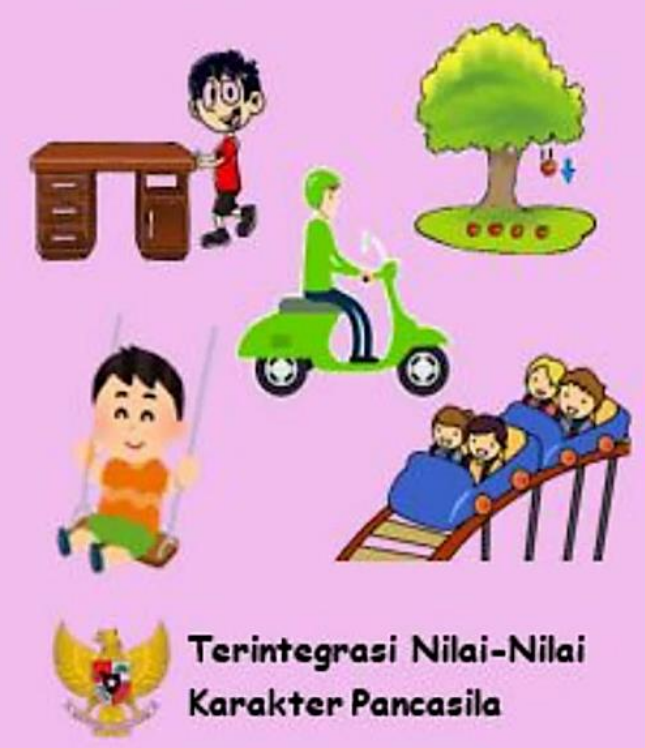

Figure 2. The E-Module Front Page 


\section{KEGIATAN BELAJAR 1}

\section{USAHA}

\section{Ayo Eksplorasi Pengetahuanmu}

T alian tentu sering mendengar istilah usaha. Apa itu usaha? Di kehidupan sehari-hari, usaha 1 atau kerja sering diartikan sebagai upaya untuk mencapai tujuan, misalnya usaha agar lulus dalam ujian, usaha untuk menjadi juara kelas, usaha untuk memenangkan lomba balap sepeda, dan usaha untuk mencapai finish dalam lomba lari. Selama orang melakukan kegiatan maka dikatakan dia berusaha, tanpa mempedulikan tercapai atau tidak tujuannya.

Analogi Kehidupan (Sila ke 5 Butir ke 9: Suka bekerja keras)

I Di dalam kehidupan, usaha (kerja) diartikan sebagai upaya yang dilakukan untuk mencapai tujuan. Artinya, untuk mencapai sebuah tujuan (cita-cita misalnya) maka diperlukan upaya sebagai bentuk usaha untuk mencapai tujuan tersebut.

Setiap orang pasti memiliki tujuan/ cita-cita dalam hidupnya. Tujuan/ cita-cita tersebut tentu saja । tidak dapat dicapai apabila kita tidak melakukan usaha. Oleh karena itu, sudah sepatutnya kita terus berusaha (bekerja) sekeras dan semaksimal mungkin agar cita-cita kita dapat tercapai.

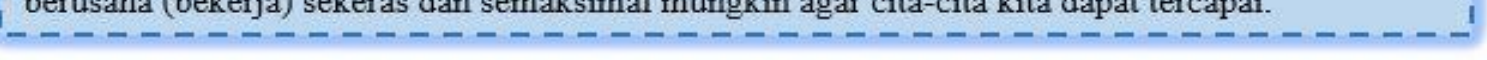

Figure 3. Material Presentation on the E-Module

(2)

\section{Contoh Soal}

1. (Sila ke 5 Butir ke 1: Mengembangkan perbuatan yang luhur, yang mencerminkan sikap dan suasana kekeluargaan dan kegotongroyongan)

Vita sedang mengikuti kegiatan kerja bakti di sekolahnya. Saat itu ia bemiat memindahkan lemari dari pojok kelas ke sisi lainnya. Namun karena lemari cukup besar, ia hanya dapat memindahkan lemari tersebut sejauh 1 meter. Melihat kejadian itu, Beni yang berada tidak jauh dari Vita datang menghampirinya. Keduanya lalu mendorong lemari tersebut bersama-sama sehingga akhirnya lemari dapat berpindah lebih jauh. Berdasarkan peristiwa tersebut, besaran apa yang menyebabkan lemari dapat berpindah lebih jauh dibandingkan sebelumnya? Mengapa lemari dapat berpindah lebih jauh ketika seseorang ikut membantu mendorong lemari? Tuliskanlah jawabanmu disertai penjelasan yang logis!

Figure 4. Example Question on the E-module

After obtaining this treatment, the student's critical thinking ability and independence in the experiment class were measured. Not only in the experiment class but measurements were also carried out in the control class. It is carried out to determine the effectiveness of e-modules.

The effectiveness of e-module in improving students 'critical thinking ability and independence is seen based on three 
analysis results, namely the analysis of improving students' critical thinking ability and independence in each class, analysis of differences in students' critical thinking ability and independence between the experiment class and the control class, and effect analysis of using e-modules on improving students' critical thinking ability and independence. The results of each are described as follows.

\section{a. The Improvement of Students' Critical} Thinking Ability and Independence in the Experiment Class and Control Class

Ten critical thinking ability test questions have been given to students. Each question contains four indicators of critical thinking ability, as previously mentioned. The score for each indicator is one if accurate and 0 if false. The correct scores obtained by the students as a whole are then added up and compared with the maximum score. The result is then multiplied by 100 to get the pretest and post-test scores. These pretest and post-test scores were used to calculate the amount of normalized gain (g) or the critical thinking ability improvement of each class. The pretest and post-test scores used in this analysis are the average scores of all respondents. The analysis results of the critical thinking ability improvement in the experiment class and control class are presented in Table 4. Besides, independence questionnaires have also been given to students.

The questionnaire contained 37 statements with four alternative answers. Each score for each alternative answer is worth 4 for strongly agree (SA), 3 for agree (A), 2 for disagree (D), and 1 for strongly disagree (SD). The score data obtained for each questionnaire statement is then converted into interval data. This is done with the Method of Successive Interval (MSI). The converted data is then added up for each respondent to obtain the pretest and post-test scores. These pretest and post-test scores were also used to calculate the amount of normalized gain ( $\mathrm{g}$ ) or the students' independence improvement in each class. The pretest and post-test scores used in this analysis are also the average scores of all respondents. The analysis results of students' independence improvement in the experiment class and control class are presented in Table 5.

Table 4. The Critical Thinking Ability Improvement

\begin{tabular}{cccc}
\hline \multicolumn{4}{c}{ Experiment Class } \\
Pretest & post-test & N Gain & Criteria \\
\hline 11.32 & 74.72 & 0.71 & High \\
\hline \multicolumn{4}{c}{ Control Class } \\
Pretest & post-test & N Gain & Criteria \\
\hline 13.24 & 52.72 & 0.45 & Moderate \\
\hline \multicolumn{5}{c}{ Table 5. The Students' Independence Improvement } \\
\hline \multicolumn{4}{c}{ Experiment Class } \\
Pretest & post-test & N Gain & Criteria \\
\hline 70.45 & 84.73 & 0.46 & Moderate \\
\hline \multicolumn{4}{c}{ Control Class } \\
Pretest & post-test & N Gain & Criteria \\
\hline 71.79 & 80.63 & 0.30 & Low \\
\hline
\end{tabular}

Table 4 shows the average score of the pretest, post-test, and normalized gain of the critical thinking ability of each class. The table shows that the experiment class obtained an n-gain value of 0.71 , which is included in the "High" criteria. In contrast, the control class received an n-gain value of 0.45 , which is included in the "Moderate" criteria. Table 5 shows the average scores of the pretest, post-test, and normalized gain for each class's students' independence. The table shows that the experiment class obtained an n-gain value of 0.46 , which is included in the "moderate" criteria. In contrast, the control class received an n-gain value of 0.30 , which is included in the "Low" criteria.

\section{b. The Differences in Students' Critical Thinking Ability and Independence between The Experiment Class and The Control Class}

The Multivariate Analysis of Variance (MANOVA) test was conducted to determine whether there were differences in students' critical thinking ability and independence between the experiment class and the control class. Still, before that, the prerequisite tests 
were carried out, namely the normality test and the homogeneity test. The data normality test results of students' critical thinking ability and independence in the experiment class and control class are presented in Table 6.

Table 6. The Data Normality Test Results

\begin{tabular}{cccc}
\hline \multicolumn{4}{c}{ Critical Thinking Ability } \\
\hline \multirow{2}{*}{ Class } & \multicolumn{3}{c}{ Shapiro-Wilk } \\
\cline { 2 - 4 } & Statistic & Df & Sig \\
\hline Experiment & 0.979 & 36 & 0.698 \\
Control & 0.971 & 34 & 0.481 \\
\hline \multicolumn{4}{c}{ Independence } \\
\hline \multirow{2}{*}{ Class } & Shapiro-Wilk \\
\cline { 2 - 4 } & Statistic & Df & Sig \\
\hline Experiment & 0.947 & 36 & 0.083 \\
Control & 0.970 & 34 & 0.472 \\
\hline
\end{tabular}

The variance-covariance homogeneity test results of students' critical thinking ability and independence data in the experimental and control classes are presented in Table 7 and Table 8.

Table 7. The Variance Homogeneity Test Results

\begin{tabular}{ccccc}
\hline \multicolumn{4}{c}{ Levene's Test of Equality of Error Variances } \\
\hline Variable & F & df1 & df2 & Sig. \\
\hline Critical Thinking & 3.237 & 1 & 68 & 0.076 \\
Ability & 0.388 & 1 & 68 & 0.536 \\
Independence & 0.388
\end{tabular}

Table 8. The Covariance Homogeneity Test Results Box's M Test of Equality of Covariance Matrices Sig. 0.074

Table 6 shows that the Shapiro-Wilk statistical test results for the normality test of the data on students' critical thinking ability and independence in the experiment class and control class overall obtained a significance of more than 0.05. Based on these results, the decision criteria taken is that $\mathrm{H}_{0}$ is accepted for all data. Students' critical thinking ability and independence data in experiment class and control class are normally distributed.

Table 7 shows that Levene's statistical test results for the variance homogeneity test of students' critical thinking ability and independence data in the experimental class and the control class as a whole obtained a significance of more than 0.05 . Based on these results, the decision criteria taken is that
$\mathrm{H}_{0}$ is accepted for all data. The data variance of students' critical thinking ability and independence between the experiment class and the control class is homogeneous. Table 8 shows the Box's $M$ test results for the covariance matrix homogeneity test, which also obtained a significance value of more than 0.05. Based on these results, the decision criteria taken is that $\mathrm{H}_{0}$ is accepted. The covariance matrix between the two groups is said to be homogeneous.

After the prerequisite test was carried out and it was known that the data were normally distributed and homogeneous, the MANOVA test was carried out. The MANOVA test results on the students' critical thinking ability and independence data of the experiment and control class are presented in Table 9.

Table 9. The MANOVA Test Results

\begin{tabular}{cccc}
\hline Effect & Value & F & Sig. \\
\hline $\begin{array}{c}\text { Hotelling's } \\
\text { Trace }\end{array}$ & 1.739 & 58.273 & 0.000 \\
\hline
\end{tabular}

Table 9 shows that the MANOVA test results on the students' critical thinking ability and independence data of the experiment class and control class with the Hotelling's Trace test obtained a significance of 0.000 . This signature value is smaller than 0.05 so that $\mathrm{H}_{0}$ is rejected. Thus, there are differences in students' critical thinking ability and independence between the experiment class and the control class.

\section{c. The Effect of Using E-Modules on} Improving Students' Critical Thinking Ability and Independence

The Output of Test of Between-Subject Effects on the MANOVA test was used to see whether or not using an e-module on the improvement of each variable, namely the students' critical thinking ability and independence. The results of the test of between-subject effects are presented in Table 10. 
Table 10. The Test of Between Subject Effects Results

\begin{tabular}{cccc} 
Results & & & \\
\hline Variable & Df & F & Sig. \\
\hline $\begin{array}{c}\text { Critical Thinking } \\
\text { Ability }\end{array}$ & 1 & 100.505 & 0.000 \\
Independence & 1 & 27.730 & 0.000 \\
\hline
\end{tabular}

Table 10 shows that the Test of BetweenSubject Effects results on each variable, namely the critical thinking ability and independence, obtain a significance value of 0.00 . This significance value is less than 0.05 , so that $\mathrm{H}_{0}$ is rejected. This means that there is an effect of using the integrated physics learning e-module with Pancasila character values to improve students' critical thinking ability. There is an effect of using the integrated physics learning e-module with Pancasila character values on strengthening students' independence.

The magnitude of the influence/ effectiveness of the integrated physics learning e-module with Pancasila character values on improving students' critical thinking ability and independence can be seen by using the effect size. The results of the effect size calculation for students' critical thinking ability and independence are presented in Table 11.

Table 11. The Calculation Results of Effect Size

\begin{tabular}{rcc}
\hline \multicolumn{3}{c}{ Critical Thinking Ability } \\
\hline Eta Square $\left(\boldsymbol{\eta}^{\mathbf{2}}\right)$ & Cohen's $\boldsymbol{f}$ & Interpretation \\
\hline 0.596 & 1.21 & Very strong \\
\hline \multicolumn{4}{c}{ Independence } \\
\hline Eta Square $\left(\boldsymbol{\eta}^{2}\right)$ & Cohen's $\boldsymbol{f}$ & Interpretation \\
\hline 0.290 & 0.64 & Very strong \\
\hline
\end{tabular}

Table 11 shows the magnitude of the influence/ effectiveness of the integrated physics learning e-module with Pancasila character values on improving students' critical thinking ability and independence, with each having an effect size of 1.21 and 0.64, which are included in the "Very Strong" category. Based on the three analysis results, it can be seen that the integrated physics learning e-module with Pancasila character values in work and energy subjects is effective in improving students' critical thinking ability and independence.

\section{Discussion}

The first result of the study shows an improvement in students' critical thinking ability and independence in each class, namely the experiment class and the control class. Table 4 more clearly shows an improvement in critical thinking ability higher in the experiment class than in the control class. Based on the table, it can be seen that initially, the experiment class had lower pretest scores than the control class but had higher post-test scores after being treated. So that from these results, the n-gain value is higher in the experiment class than in the control class. This means an improvement in the critical thinking ability is higher in the experiment class than in the control class. This may be due to the presentation of various components in the emodule, which used by the experiment class are adjusted to the critical thinking ability indicators. It allows students to think critically. The presentation of these various components will enable students to understand, practice, and get used to analyzing facts/ problems, formulating problems main, defending/ selecting/ clarifying/ evaluating logical arguments, and making decisions/ conclusions related to work and energy. In addition, Table 5 more clearly also shows that there is an improvement in student independence that is higher in the experiment class than in the control class. Like critical thinking ability, initially, the experiment class had lower pretest scores than the control class but had higher post-test scores than the control class. These results lead to a higher $\mathrm{n}$-gain value in the experiment class. This means an independence improvement is greater in the experiment class than in the control class. This may be due to the presentation of various components in the e-module used by the experiment class provides examples of events related to the Pancasila character values, so enabling students to gain new insights and to be motivated to show attitudes related to those values, including the value of the independence character. The simple 
inquiry activities on this e-module also encourage students to be independent. But it also needs to be remembered. The magnitude of the independence improvement is not too large, only included in the medium criteria for the experiment class and low standards for the control class. This may be because it takes time for these characters to develop through more intense habituation. Based on these results, it can be seen that the experiment class that uses the integrated physics learning e-module with Pancasila character values in work and energy subjects has improved critical thinking ability and independence higher than the control class that is not used e-module.

The second result of the study shows differences in students' critical thinking ability and independence between the experiment class and the control class. Table 9 more clearly shows the Hotelling's Trace test result in the MANOVA test on students' critical thinking ability and independence data of experiment and control class who obtained a significance of 0.000 . Based on these results, it can be seen that there are differences in students' critical thinking ability and independence between the experiment class that uses the integrated physics learning e-module with Pancasila character values in work and energy subjects with the control class that does not use the emodule.

The third result of the study shows there is the effect of using e-modules in improving students' critical thinking ability and independence. Table 10 more clearly shows the output results of the test of BetweenSubject Effects on the MANOVA test on students' critical thinking ability and independence data in the experiment class and the control class. Based on the table, it can be seen that the two variables, namely critical thinking ability and independence, have the same significance of 0.000 . Based on these results, it can be seen that there is an effect of using integrated physics learning emodule with Pancasila character values in work and energy subjects on the improvement of the two variables, namely students' critical thinking ability and independence. The magnitude of the influence/ effectiveness of the e-module on improving critical thinking ability is shown by the calculation of the effect size, where the critical thinking ability variable has an eta square value of 0.596 and a cohen's $f$ value which is an effect size value of 1.21. The effect of using an e-module on the improvement of the critical thinking ability variable is included in the "Very Strong" category. The student independence variable has an eta square value of 0.290 and a cohen's $\mathrm{f}$ value, an effect size value of 0.64 . The effect of using an e-module on improving student independence variables is also included in the "Very Strong" category. As previously mentioned, this may happen because the various components of the emodule that used students provide students with the opportunity to practice critical thinking ability and develop independence. Besides that, it also presents examples of character values in life through learning physics. Physics learning becomes more attractive, improving students' insight or awareness of the importance of character values, including independence in life.

These three findings indicate that integrated physics learning e-module with Pancasila character values in work and energy subjects effectively improve students' critical thinking ability and independence. This is because the module is one of the teaching materials designed to train or support students in improving specific skills, including critical thinking ability and students' independence. Modules are packaged comprehensively and systematically, containing a sequence of learning experiences designed and planned to aid students to reach specific learning aims (Daryanto, 2013; Ramdani et al., 2019). Regarding the attempt to improve the critical thinking ability of students, a series of learning activities presented in the module can be designed in such a way that it can train the student to think critically (Hidayati et al., 
2019). Some of them are done by presenting a series of learning activities that are more student-centered and emphasizing students' memorization. Still, students are given problems to improve their thinking ability (Hamdani et al., 2019). A series of learning activities presented in the module can also involve mental processes, for example, paying attention, grouping, selecting, deciding, and drawing conclusions to improve critical thinking ability (Husnaeni, 2016). Another opinion suggests that improvement efforts to improve critical thinking ability with discovery learning focus on allowing students to construct knowledge actively. That is to say, knowledge is discovered, formed, and expanded by students in groups and individually utilize cooperative learning (Lie, 2004). A series of learning activities in the module can also complement exercises to improve students' critical thinking ability. One thing that is no less important in teaching thinking ability is the need for intensive exercises. Like other skills, in thinking ability, students need to repeat to practice it even though this ability has become part of their thinking. Regular exercises that students carry out will impact the efficiency and automation of students' thinking ability (Yen \& Halili, 2015).

As for efforts to improve student independence, modules can support and accustom students to be independent, especially in learning activities. This is because the module has traits including stand-alone, self-contained, selfinstructional, user friendly, and adaptive. These characteristics can support learners to learn independently without being tied to or dependent on other parties, studying the material in its entirety, can be used independently or linked to additional teaching materials, flexible and adaptable to technological developments, and not difficult to implement/ use (Husna et al., 2020; Rohmiyati et al., 2016; Sukiman, 2012). According to Williams, independence can be developed by giving real responsibility to students, providing clear goals to students and allowing students to determine when they are ready to continue learning, providing models and frameworks to support investigative activities, not only providing answers, providing practical assignments for student independence, and so forth (Jones, 2019; Williams, 2003; Zheng et al. 2018). These various things can be presented and obtained by students through modules. Related to efforts to improve independence, which is also one of the important characters that students must-have in the 21 st century, the presentation of material in the module can also be integrated with the Pancasila character values character of independence. This is done as a form of effort in character education. According to the Guidelines of Kemendiknas, integrated character education in the learning process can be implemented by introducing values, facilitating consciousness of the importance of value, and internalizing values inside the daily activities of students utilizing a good learning process that takes goes on outside and inside the classroom in all subjects (Kementerian Pendidikan Nasional, 2010). Another method that can be done is the inculcation method, modeling (exemplary), facilitation, and skillbuilding (Kirschenbaum, 1995). Therefore, the use of modules can support students in improving their critical thinking ability and independence.

These findings are conformable with the research conducted by Retnowati, Riyadi, \& Subanti (2020), Putri \& Aznam (2019), Restika, Wibowo, \& Linuwih (2020), Utami, Triwoelandari, \& Nawawi (2019), and Puspitasari (2019). Retnowati, Riyadi, \& Subanti (2020), in their research, developed a rectangular module that applies a STEM approach to improving critical thinking ability. Their results research indicates that the module is proven effective. It is reflected from the $n$-gain average value of the experiment class of 0.37 with a moderate improvement category, whereas the control class is 0.03 with a low improvement category. Putri \& Aznam (2019) conducted a study to determine the effect of the integrated 
science web module on the local potential of batik on critical thinking and problemsolving ability. The results indicated a distinction in students' thinking abilities among the control class and the experiment class, as shown by the Kruskal Wallis test, which gave significant output. This module has a significant effect on students' thinking skills, as demonstrated by Cohen's effect size score of 0.8 .

Restika, Wibowo, \& Linuwih (2020), in their research, implemented a guided discovery-based thematic learning module to improving independence and learning achievement. The results of his research indicated that the module was effective in improving student independence and learning achievement. Student independence and achievement improved significantly based on the paired t-test at a significance level of 0.05 (sig. $(2$ tailed $)=$ $0.000<\mathrm{a}=0.05)$. Utami, Triwoelandari, \& Nawawi (2019) researched the effect of the integrated science learning module on religious values on developing students' independent character. The results show the module affects the development of students' independence. Puspitasari (2019), in his research, developed a module filled with character values with an inquiry model for temperature and heat physics material for the tenth grade. The results showed that this physics module could help develop character values in students and can motivate students to learn independently.

\section{CONCLUSION AND SUGGESTION}

Based on the data analysis results and discussion that has been done, it can be concluded that the integrated physics learning e-module with Pancasila character values in work and energy subjects is effective in improving students' critical thinking ability and independence. This is evidenced by the acquisition of three analysis results, which show that there is an improvement in students 'critical thinking ability and independence that is higher in the experiment class than in the control class after being given treatment, there are differences in students' critical thinking ability and independence between the experiment class and the control class, and there is an effect of using e-module on the two variables improvement where the magnitude of this influence is included in the very strong category. Concerning these results, teachers and students can take advantage of this e-module as a reference learning source because it has been proven to improve students' critical thinking ability and independence. It is also important for teachers to design learning resources that can practice specific skills and relate them to other learning, such as character values so that learning becomes more interesting, innovative, and meaningful. Given the limitations of the material, character values, and variables that will be improved through this e-module, teachers or researchers in the future can develop an integrated physics learning e-module with Pancasila character values in other physics material by integrating different character values, as well as to improve other variables. Further research can also use three treatment classes so that the Post-Hoc test can be carried out and with a more extended research duration so that the character development can be better observed.

\section{ACKNOWLEDGMENT}

Thanks to DRPM Kemristekdikti, which funded this research through the master thesis research grant scheme number T/9.45/UN34.21/PT.01.03/2020. Thanks also presented to the Institute for Research and Community Service (LPPM) Yogyakarta State University for facilitating the research.

\section{REFERENCES}

Adi, P. (2016). Pembudayaan nilai-nilai pancasila bagi masyarakat sebagai modal dasar pertahanan nasional NKRI. Jurnal Moral Kemasyarakatan, 1(1), 39. https://doi.org/10.21067/jmk.v1i1.1185

Agung, F. P., Suyanto, S., \& Aminatun, T. (2020). E-Modul gerak refleks berbasis pendekatan kontekstual untuk 
meningkatkan pemahaman konsep siswa SMA. Jurnal Pendidikan: Teori, Penelitian, Dan Pengembangan, 5(3), 280.http://dx.doi.org/10.17977/jptpp.v5i 3.13238

Ahmadi, F., \& Ibda, H. (2018). Media literasi sekolah: Teori dan praktik. CV Pilar Nusantara.

Anita, A., \& Novianty, F. (2020). The students' characters analysis in physics learning process. Jurnal Penelitian \& Pengembangan Pendidikan Fisika, 6(1), 75. https://doi.org/10.21009/1.06108

Aprilia, I., \& Suryadarma, I. G. P. (2020). Emodule of mangrove ecosystem (emme): Development, validation and effectiveness in improving students' selfregulated. Biosfer, 13(1), 116-117. https://doi.org/10.21009/biosferjpb.v13n 1.114-129

Ariyani, F., Nayana, T., Saregar, A., Yuberti, Y., \& Pricilia, A. (2018). Development of photonovela with character education: As an alternative of physics learning media. Jurnal Ilmiah Pendidikan Fisika AlBiruni, $7(2), \quad 227$. https://doi.org/10.24042/jipfalbiruni.v7i2 .3072

Asrial, A., Syahrial, S., Maison, M., Kurniawan, D. A., \& Piyana, S. O. (2020). Ethnoconstructivism e-module to improve perception, interest, and motivation of students in class $\mathrm{V}$ elementary school. JPI (Jurnal Pendidikan Indonesia), 9(1), 30-31. http://dx.doi.org/10.23887/jpiundiksha.v9i1.19222

Astra, I. M., Raihanati, \& Mujayanah, N. (2020). Development of electronic module using creative problem-solving model equipped with HOTS problems on the kinetic theory of gases material. Jurnal Penelitian dan Pengembangan Pendidikan Fisika, 6(2), 182. https://doi.org/10.21009/1.06205

Astuti, B., \& Mufrihah, A. (2019). Arrangment of responsibility character module using expert validation. Journal of Education and Learning (EduLearn), 13(3), 402. https://doi.org/10.11591/edulearn.v13i3. 9808
Aulia, L. N., Susilo, S., \& Subali, B. (2019). Upaya peningkatan kemandirian belajar siswa dengan model problem-based learning berbantuan media Edmodo. Jurnal Inovasi Pendidikan IPA, 5(1), 71. https://doi.org/10.21831/jipi.v5i1.18707

Buana, V. G., \& Kasanah, S. U. (2019). Pengembangan model pembelajaran berbasis permainan engklek kelas IV sekolah dasar. Jurnal Penelitian Inovasi Pembelajaran, $\quad 4(2), \quad 132$. https://doi.org/10.29407/pn.v4i2.12585

Chrisyarani, D. D., \& Yasa, A. D. (2018). Validasi modul pembelajaran: Materi dan desain tematik berbasis PPK 1,2. Jurnal Pendidikan Dasar Dan Pembelajaran, $8(2)$, 207-208. https://doi.org/10.25273/pe.v8i2.3207

Cohen, J. (1988). Statistical Power Analysis for Behavorial Sciences (2nd ed.). Hillsdale N.J: L.Erlbaum Associates.

Darmaji, D., Kurniawan, D. A., Astalini, A., Kurniawan, W., Anwar, K., \& Lumbantoruan, A. (2019). Students' perceptions of electronic's module in physics practicum. Journal of Education and Learning (EduLearn), 13(2), 289. http://dx.doi.org/10.11591/edulearn.v13i 2.13005

Daryanto. (2013). Menyusun modul bahan ajar untuk persiapan guru dalam mengajar. Gava Media.

Derlina, D., \& Srijayanti, P. (2016). Potret implementasi pendidikan karakter di SMP kecamatan patumbak sumatera utara. Jurnal Ilmiah Pendidikan Fisika AlBiruni, 5(2), 142. https://doi.org/10.24042/jpifalbiruni.v5i2 .114

Ghozali, R. Al, \& Wahyuningsih, Y. (2017). Pendidikan berbasis ajaran agama dan kebudayaan masyarakat indonesia dalam menghadapi arus globalisasi. Cakrawala Dini, $\quad 8(2), \quad 4$. https://doi.org/10.17509/cd.v8i2.10536

Hake, R. (1998). Interactive-engagement versus traditional methods: A sixthousand-student survey of mechanics test data for an introductory physics course. American Journal of Physics, 66(1),

64-74. 
https://doi.org/10.1119/1.18809

Hamdani, Prayitno, \& Karyanto. (2019). Meningkatkan kemampuan berpikir kritis melalui metode eksperimen the improveability to think critically through the experimental method. Proceeding Biology Education Conference, 16(1), 140-142.

Harjo, B., Kartowagiran, B., \& Mahmudi, A. (2019). Development of critical thinking skill instruments on mathematical learning high school. International Journal of Instruction, 12(4), 150-151. https://doi.org/10.29333/iji.2019.12410a

Hidayati, N., Pangestuti, A. A., \& Prayitno, T. A. (2019). Edmodo mobile: Developing e-module biology cell for online learning community. Biosfer, 12(1), 95. https://doi.org/10.21009/biosferjpb.v12n 1.94-108

Husna, A., Hasan, M., Mustafa, Syukri, M., \& Yusrizal. (2020). Pengembangan modul fisika berbasis integrasi islam-sains pada materi gerak lurus untuk meningkatkan hasil belajar peserta didik. Jurnal Pendidikan Sains Indonesia, 8(1), 57. https://doi.org/10.24815/jpsi.v8i1.15539

Husna, I. Y. Al, Masykuri, M., \& Muzzazinah. (2021). Development of Instructional module based on inquiry-interactive demonstration to improve students' critical thinking skills. Jurnal Ilmu Pendidikan Fisika, 6(1), 67. http://dx.doi.org/10.26737/jipf.v6i1.1840

Husnaeni. (2016). The enhancement of mathematical critical thinking ability of aliyah madrasas student model using gorontalo by interactive learning setting cooperative model. Journal of Education and Practice, 7(8), 159. https://www.iiste.org/Journals/index.php/ JEP/article/view/29404

Izzati, U. A., Bachri, B. S., Sahid, M., \& Indriani, D. E. (2019). Character education: Gender differences in moral knowing, moral feeling, and moral action in elementary schools in Indonesia. Journal for the Education of Gifted Young Scientists, $\quad 7(3), \quad 548$. https://doi.org/10.17478/jegys.597765

Janah, I. N., Chamisijatin, L., \& Husamah.
(2018). Implementasi Pendidikan karakter dalam pembelajaran IPA di SMPN XY Kota Malang. Jurnal Biotek, 6(1), https://doi.org/10.24252/jb.v6i1.4243

Jones, J. A. (2019). Scaffolding self-regulated learning through student-generated quizzes. Active Learning in Higher Education, 20(2), 115. https://doi.org/10.1177/14697874177356 10

Kementerian Pendidikan Nasional. (2010). Bahan pelatihan penguatan metodologi pembelajaran berdasarkan nilai-nilai budaya untuk membentuk daya saing dan karakter bangsa. Pusat Kurikulum, Badan Penelitian dan Pengembangan.

Kirschenbaum, H. (1995). 100 ways to enhance values and morality in schoolsand youth settings. Allyn \& Bacon.

Kurniasih, H. R., Edwita, \& Siswono, E. (2018). Penguatan pendidikan karakter melalui pengembangan proses pembelajaran. Prosiding Seminar Dan Diskusi Nasional Pendidikan Dasar, 249.

Kurniawan, R., \& Syafriani, S. (2020). Media analysis in the development of e-module based guidance inquiry integrated with ethnoscience in learning physics at senior high school. Journal of Physics: Conference Series, 1481(1), 1. https://doi.org/10.1088/17426596/1481/1/012062

Labudasari, E., \& Rochmah, E. (2019). Pengaruh gerakan literasi sekolah terhadap karakter mandiri siswa di SDN Kanggraksan Cirebon. Jurnal Pendidikan Dasar Dan Pembelajaran, 9(1), 58. https://doi.org/10.25273/pe.v9i1.4254

Lie, A. (2004). Cooperative learning. Gramedia.

Malihah, E. (2015). An ideal Indonesian in an increasingly competitive world: Personal character and values required to realise a projected 2045 'Golden Indonesia.' Citizenship, Social and Economics Education, 14(2), 148-156. https://doi.org/10.1177/20471734155971 43

Musawwamah, S. (2019). Penguatan karakter dalam pendidikan sistem persekolahan 
(implementasi PERPRES nomor 87 tahun 2017 tentang penguatan pendidikan karakter). Jurnal Penelitian Ilmu Sosial dan Kegamaan Islam, 16(1), 42. http://dx.doi.org/10.19105/nuansa.v16i1. 2369

Nisa, E. K., Jatmiko, B., \& Koestiari, T. (2018). Development of guided inquiry-based physics teaching materials to increase critical thinking skills of highschool students. Jurnal Pendidikan Fisika Indonesia, $14(1), \quad 19$. https://doi.org/10.15294/jpfi.v14i1.9549

Noor, J. (2017). Metodologi penelitian: skripsi, tesis, disertasi, dan karya ilmiah. KENCANA.

Nurazizah, S., Sinaga, P., \& Jauhari, A. (2017). Profil kemampuan kognitif dan keterampilan berpikir kritis siswa sma pada materi usaha dan energi. Jurnal Penelitian \& Pengembangan Pendidikan Fisika, 3(2), 197. https://doi.org/10.21009/1.03211

Putri, S. M., Sulastri, \& Saminan. (2017). Mempersiapkan generasi peduli lingkungan melalui pembelajaran senyawa karbon bermuatan nilai karakter. Jurnal Pendidikan Sains Indonesia, 5(2), 104.

https://doi.org/10.24815/jpsi.v5i2.9824

Ramadoni, A., Yulkifli, \& Ratnawulan. (2019). Development of physics module SMA/MA integrated character values based on discovery learning models with approach science process skills. Journal of Physics: Conference Series, 1185(1). https://doi.org/10.1088/17426596/1185/1/012068

Ramdani, R., Syamsuddin, A., \& Sirajuddin, S. (2019). Development of mathematical module-problem solving approach to train student's reflective thinking. Pedagogical Research, 4(4), 3. https://doi.org/10.29333/pr/5861

Retnowati, S., Riyadi, \& Subanti, S. (2020). The Stem Approach: The development of rectangular module to improve critical thinking skill. International Online Journal of Education and Teaching (IOJET), $7(1)$ 2. http://iojet.org/index.php/IOJET/article/v iew/704

Rohmiyati, N., Ashadi, A., \& Utomo, S. B. (2016). Pengembangan modul kimia berbasis inkuiri terbimbing pada materi reaksi oksidasi - reduksi. Jurnal Inovasi Pendidikan IPA, 2(2), 225. https://doi.org/10.21831/jipi.v2i2.4869

Rufii, R. (2015). Developing module on constructivist learning strategies to promote students' independence and performance. International Journal of Education, $\quad 7(1), \quad 18$. https://doi.org/10.5296/ije.v7i1.6675

Sadaghiani, H. R. (2012). Controlled study on the effectiveness of multimedia learning modules for teaching mechanics. Physical Review Special Topics - Physics Education Research, 8(1), 1. https://doi.org/10.1103/PhysRevSTPER. 8.010103

Saefullah, A., Siahaan, P., \& Sari, I. M. (2017). The correlation of learning independence attitudes and student's learning achievement on physics learning based portfolio. Jurnal Penelitian Dan Pembelajaran IPA, 3(1), 75-76. http://dx.doi.org/10.30870/jppi.v3i1.174 1

Saputra, M. R. D., \& Kuswanto, H. (2019). The effectiveness of physics mobile learning (PML) with Hombo Batu theme to improve the ability of diagram representation and critical thinking of senior high school students. International Journal of Instruction, 12(2), 474. https://doi.org/10.29333/iji.2019.12230a

Siswanto, Yusiran, \& Fajaudin. (2016). Keterampilan proses sains dan kemandirian belajar siswa. Jurnal Ilmiah Penelitian dan Pembelajaran Fisika, 2(2), http://dx.doi.org/10.30870/gravity.v2i2.1 136

Sofyan, H., Anggereini, E., \& Saadiah, J. (2019). Development of E- modules based on local wisdom in central learning model at kindergartens in Jambi city. European Journal of Educational Research, $8(4), \quad 1138$. https://doi.org/10.12973/eu-jer.8.4.1139

Sopacua, J., Fadli, M. R., \& Rochmat, S. 
(2020). The history learning module integrated character values. Journal of Education and Learning (EduLearn), 14(3), 463. https://doi.org/10.11591/edulearn.v14i3. 16139

Sukiman. (2012). Pengembangan media pembelajaran. PT Pustaka Insan Madani.

Sunaengsih, C. (2017). Buku ajar pengelolaan pendidikan. UPI Sumedang Press.

Supardi, S. U. S. (2018). Developing of measurement of independence characteristic in middle school student's mathematics and science. Formatif: Jurnal Ilmiah Pendidikan MIPA, 8(2), 112.

http://dx.doi.org/10.30998/formatif.v8i2. 2650

Susanti, N., \& Djukri, D. (2018). Pengembangan modul biologi materi pokok ekosistem berbasis aktivitas siswa di pondok pesantren untuk menanamkan sikap spiritual dan kemandirian siswa developing a biology module in ecosystem subject based o $\mathrm{n}$ student' $\mathrm{s}$ activity at islamic boarding schoo. Jornal Inovasi Pendidikan IPA, 4(1), 66. https://doi.org/10.21831/jipi.v4i1.5995

Syawaludin, A., Gunarhadi, \& Rintayati, P. (2019). Development of augmented reality-based interactive multimedia to improve critical thinking skills in science learning. International Journal of Instruction, $\quad 12(4), \quad 332$. https://doi.org/10.29333/iji.2019.12421a

Tanti, Maison, Syefrinando, B., Daryanto, M., \& Salma, H. (2020). Students' selfregulation and motivation in learning science. International Journal of Evaluation and Research in Education, 9(4), 866. https://doi.org/10.11591/ijere.v9i4.20657

Ummah, R., Suarsini, E., Lestari, R., \& Biologi, P. (2020). Pengembangan emodul berbasis penelitian uji antimikroba pada matakuliah mikrobiologi. Jurnal Pendidikan: Teori, Penelitian, Dan Pengembangan, 5(5), 572-579. http://dx.doi.org/10.17977/jptpp.v5i5.13 432

Walsh, C., Quinn, K. N., Wieman, C., \&
Holmes, N. G. (2019). Quantifying critical thinking: Development and validation of the physics lab inventory of critical thinking (PLIC). Physical Review Physics Education Research, 15(1), 2. https://doi.org/10.1103/physrevphyseduc res. 15.010135

Williams, J. (2003). Promoting independent learning in the primary classroom. Open University Press.

Wrahatnolo, T., \& Munoto. (2018). 21st centuries skill implication on educational system. IOP Conference Series: Materials Science and Engineering, 296. https://doi.org/10.1088/1757899X/296/1/012036

Yen, T. S., \& Halili, S. H. (2015). Effective teaching of higher-order thinking (HOT) in education. The Online Journal of Distance Education and E-Learning, 3(2), 43.

Zheng, L., Li, X., \& Chen, F. (2018). Effects of a mobile self-regulated learning approach on students' learning achievements and self-regulated learning skills. Innovations in Education and Teaching International, 55(6), 2. https://doi.org/10.1080/14703297.2016.1 259080 